\title{
Abundance and Species Diversity of Fungi in Rivers with Various Contaminations
}

\author{
A. Pietryczuk ${ }^{1} \cdot$ A. Cudowski ${ }^{1} \cdot$ T. Hauschild $^{2} \cdot$ M. Świsłocka ${ }^{3} \cdot$ A. Więcko ${ }^{1} \cdot$ M. Karpowicz $^{1}$
}

Received: 23 August 2017 / Accepted: 26 December 2017 / Published online: 30 December 2017

(c) The Author(s) 2017. This article is an open access publication

\begin{abstract}
The main objective of this work was to determine the abundance and species diversity of fungi in the waters of selected rivers of Central Europe, NE Poland (Augustów Lakeland), differing in size, physical and chemical properties, and streamflow rate. The minimum abundance of fungi in the analysed rivers was recorded for a river with low concentration of organic matter ( $8200 \mathrm{CFU} / \mathrm{mL}$, Czarna Hańcza River), and maximum for a strongly anthropogenically polluted river (24,800 CFU/ $\mathrm{mL}$, Kamienny Bród River). A total of 49 fungal species were identified based on PCR ITS-RFLP and DNA sequencing methods. However, RFLP-PCR method has proved to be sufficient to determine the species of 34 fungi. The highest taxonomic diversity was determined for the waters abundant in organic matter (Piecówka and Rospuda Rivers), and the lowest for rivers poor in organic matter (Netta and Czarna Hańcza Rivers). From the 49 identified species, $47 \%$ were aquatic hyphomycetes, and $18 \%$ were potentially pathogenic fungi mainly occurring in the waters of polluted rivers with increased organic matter concentrations. Moreover, a higher number of fungal taxa were recorded in fluvial waters distinguished by higher streamflow rate, and therefore, stronger water turbulence. The study results suggest that the most important factors influencing the structure of mycoplankton in rivers include $\mathrm{pH}$ of water, content of organic matter, degree of anthropogenic pollution, and streamflow rate.
\end{abstract}

\section{Introduction}

Fungi fulfil very substantial functions in such environments. In most of all they are important elements of the microbial loop. Together with bacteria, they initiate the decomposition of organic matter, particularly that of plant origin, preparing the substratum to be inhabited by other organisms, particularly invertebrates [41]. It has been evidenced that only some few hours after falling into streams, leaves are covered with a biofilm of microorganisms with a definite prevalence of fungi [30]. Moreover, fungi inhabiting water ecosystems actively participate in the production of autochthonic humic substances

A. Cudowski

cudad@uwb.edu.pl

1 Department of Hydrobiology, Institute of Biology, University of Białystok, Ciołkowskiego 1J, 15-245 Białystok, Poland

2 Department of Microbiology, Institute of Biology, University of Białystok, Ciołkowskiego 1J, 15-245 Białystok, Poland

3 Department of Molecular Zoology, Institute of Biology, University of Białystok, Ciołkowskiego 1J, 15-245 Białystok, Poland
[11]. These microorganisms also actively participate in the circulation of nutrients such as nitrogen and phosphorus [8]. They can be suspended in the water depths, settled on the bottom or periphyton, be directly supplied to waters with surface runoff, or be of anthropogenic origin. Certain fungal species supplied to the water depths cause diseases in fish and other aquatic animals, as well as in humans [18]. On the other hand, they have been evidenced to actively participate in the biotransformation of xenobiotics [24] and heavy metals [41] supplied to the aquatic environment, potentially contributing to the alleviation of the effects of anthropogenic stress, and improving water quality. Due to this, a lot of authors have proposed to include these organisms in the group of bioindicators of anthropogenic alterations in the monitoring of the ecological state of aquatic ecosystems [5, 32, 39], and the sanitary state of waters $[4,10]$. Research regarding the abundance [21, 33 ] and taxonomic identification of aquatic fungi in various types of waters, and particularly in lakes with varied trophic status [6, 20,34], has been increasingly frequent in the recent years. Attempts to explain the effect of physical and chemical water parameters on the species diversity and abundance of mycoplankton, particularly in flowing waters, are very scarce. That is why the main goal of this manuscript is identification 
of taxonomic structure and abundance of fungi in rivers with various streamflow rate and contaminations determined by nutrients $(\mathrm{C}, \mathrm{N}$ and $\mathrm{P})$ and sulphate and chloride ions which are indicators of anthropogenic pollution. It will be helpful to understanding of functioning aquatic fungi in different type of flowing surface water. It could allow for the future application of this group of organisms as bioindicators of the ecological state, and indicators of the sanitary quality of waters.

\section{Materials and Methods}

\section{Study Area}

The study area included a group of five rivers located in Central Europe (Poland). The Rospuda, Netta, and Kamienny Bród Rivers are located in the catchment of the Vistula River, and the Piecówka and Czarna Hańcza Rivers in the catchment of the Neman River. The Kamienny Bród River flows through areas under agricultural use, and the Piecówka and Rospuda Rivers through developed areas supplying household sewage to the rivers. The Czarna Hańcza and Netta Rivers flow through areas without human intervention. The monitoring of the rivers was conducted in the hydrological year 2013 in favourable meteorological conditions permitting credible results.

\section{Collection of Material for Analysis}

$\mathrm{Al}$ water samples for chemical and molecular analysis were collected four times in different hydrological seasons in January, May, August, and October of the hydrological year 2013 using a Limnos sampler from a depth of $0.5 \mathrm{~m}$ in the midstream. The samples were collected from each river in two

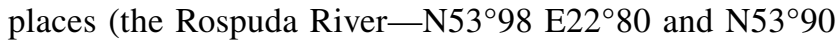
E $22^{\circ} 95$, the Netta River-N53 80 E $22^{\circ} 97$ and N53 ${ }^{\circ} 67$ E22 ${ }^{\circ} 89$, the Kamienny Bród River-N53 ${ }^{\circ} 93$ E22 ${ }^{\circ} 82$ and N53 ${ }^{\circ} 87$ E22 ${ }^{\circ} 90$, the Piecówka River-N53 88 E23 45 and

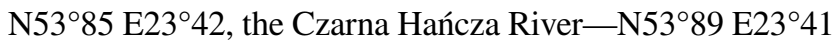
and $\mathrm{N} 54^{\circ} 24 \mathrm{E} 22^{\circ} 80$ ). Moreover, the streamflow rate (SQ) of river waters was measured using an ADC digital current meter (OTT) (Table 1). The water samples for mycological and chemical analyzes were transported to the laboratory in glass bottles $(1 \mathrm{~L})$ in a cool $\left(0-4{ }^{\circ} \mathrm{C}\right)$ and in the dark with accordance to the PN-EN ISO 19458, ISO 5667-5: 2003.

\section{The Physico-chemical Water Quality}

Water temperature, electrolytic conductivity (EC), oxygen saturation, dissolved oxygen concentration and $\mathrm{pH}$ were measured in the field using a HQ40D Hach Lange meter. Analysis of the basic chemical water parameters was conducted in laboratory. They determined concentrations of sulphate(VI), chloride and phosphorous ions as well as nitrate(V), nitrate(III), ammonium which allowed for calculating the total inorganic nitrogen (TIN) according to standards methods [1]. Chlorophyll $a$ concentration was determined according to PN-86/C-05560/02 [35]. The concentration of dissolved organic carbon (DOC) was determined by the high-temperature catalytic method of incineration in a TOC-5050A analyser (Shimadzu), and particulate organic carbon (POC) was determined by the chromate method [7]. Phenols concentration was determined according to Lowry et al. [26] method.

\section{The Abundance of Fungi}

To estimate fungal abundance, $250 \mu \mathrm{L}$ of unfiltered water, diluted to ratios of 1:10 and 1:100, were placed on Sabouraud agar plates enriched in chloramphenicol $(0.05 \mathrm{~g} / \mathrm{L})$ and incubated for 5 days at either 37,25 or $5^{\circ} \mathrm{C}$ (due to differences in optimum growth temperature). After incubation, the numbers of colonies $(\mathrm{CFU} / \mathrm{mL})$ were determined [12].

\section{The Taxonomic Structure of Fungi}

DNA was isolated from fungal cells using Genomic Mini AX Yeast and Bead-Beat Micro Gravity DNA Isolation Kit (A\&A Biotechnology) according to the manufacturer's protocol. The reaction mixture for PCR amplification per one sample contained $2 \mu \mathrm{L}$ of isolated DNA, 10 pmol of ITS 1 primer (5'TCCGTAGGTGAACCTGCGG-3'), 10 pmol of ITS4 primer (5'-TCCTCCGCTTATTGATATGC-3') [17], $11.75 \mu \mathrm{L}$ of nuclease-free water (A\&A Biotechnology), and $12.5 \mu \mathrm{L}$ of PCR Master MixPlus (A\&A Biotechnology). The PCR reaction was performed in a GeneAmp PCR System 9600 thermal cycler (Applied Biosystems) under the following conditions: initial denaturation for $3 \mathrm{~min}$ at $95^{\circ} \mathrm{C}, 40$ cycles consisting of denaturation at $95^{\circ} \mathrm{C}$ for $1 \mathrm{~min}$, annealing at $52^{\circ} \mathrm{C}$ for $1 \mathrm{~min}$, extension at $72{ }^{\circ} \mathrm{C}$ for $1 \mathrm{~min}$ and final extension step at $72{ }^{\circ} \mathrm{C}$ for $10 \mathrm{~min}$. The presence of a PCR product was confirmed by $1 \%(\mathrm{wt} / \mathrm{vol})$ agarose gel electrophoresis and visualised with ethidium bromide (Gel DOC XR(TM) Imaging System,
Table 1 The average values (in bold) and minimum-maximum of streamflow quantity (SQ) of analysed rivers water

\begin{tabular}{llllll}
\hline Rivers & Kamienny Bród & Piecówka & Rospuda & Netta & Czarna Hańcza \\
\hline $\mathrm{SQ}\left(\mathrm{m}^{3} / \mathrm{s}\right)$ & $\mathbf{0 . 6 3}$ & $\mathbf{0 . 5 4}$ & $\mathbf{8 . 0 9}$ & $\mathbf{8 . 1 3}$ & $\mathbf{7 . 3 0}$ \\
& $0.45-0.84$ & $0.46-0.63$ & $7.79-8.61$ & $7.18-9.19$ & $6.62-7.59$ \\
\hline
\end{tabular}


Bio-Rad). Amplified PCR products were sequenced with the BigDye $^{\text {TM }}$ Terminator Cycle Sequencing Ready Reaction Kit v 3.1 (Applied Biosystems) in both the forward and reverse directions using the amplification primers. The sequencing reaction proceeded with the following sequencing profile parameters: preliminary denaturation at temperature $94{ }^{\circ} \mathrm{C}$ for 3 min followed by 25 cycles of denaturation at $94{ }^{\circ} \mathrm{C}$ for $30 \mathrm{~s}$, primer attachment at $50{ }^{\circ} \mathrm{C}$ for $15 \mathrm{~s}$ and elongation at $60{ }^{\circ} \mathrm{C}$ for $4 \mathrm{~min}$. Unincorporated dideoxynucleotides were eliminated from the sequencing reaction using the ExTerminator Kit (A\&A Biotechnology) and then the sequencing products were subjected to electrophoresis and direct analysis in an automatic sequencer (Applied Biosystems). To read, adjust and align the sequence, commonly used computer software was used: Chromas Lite v.2.01 (Technelysium Pty Ltd, 2005) and BioEdit Sequence Alignment Editor v.7.0.1 [19].

The DNA digestions were performed with $10 \mu \mathrm{L}$ of PCR product in a total volume of $15 \mu \mathrm{L}$ with $1 \times$ reaction buffer and $10 \mathrm{U}$ of EcoRI endonuclease (Sigma-Aldrich) for $2 \mathrm{~h}$ at $37{ }^{\circ} \mathrm{C}$. The resulting fragments were separated by electrophoresis on a $2 \%$ agarose gel and visualised under UV light after ethidium bromide staining [14]. The lengths of the products were evaluated using a $1000 \mathrm{pb}$ DNA ladder. The results were archived using Gel Doc 2000 equipment (BioRad) and the software program Quantity One. The lengths of the DNA fragments separated on a gel after digestion were compared to the fragment lengths of the reference strains in GenBank.

\section{Statistical Analysis}

To investigate the relationships between environmental and biological data, a redundancy analysis (RDA) was carried out. RDA is an enhancement of the commonly applied principal component analysis (PCA); however, unlike PCA, RDA allows direct analysis of biotic-environmental components $[42,43]$. To test whether RDA analysis was appropriate for the dataset, the data were first tested for normality (Kolmogorov-Smirnov test). DCA was used first to determine the pattern of variability in the studied assemblages: if the length of the first gradient was $>2$ standard deviations, we assumed a unimodal variation; a length $<2$ SD indicates a linear variation [25]. The length of the first gradient for the fungi communities was $1.71 \mathrm{SD}$, indicating linear variation, justifying RDA. Correlation coefficients were calculated with Pearson ranks. The analysis of existing differences among rivers involved multi-dimensional analysis, specifically, cluster analysis, where the Euclidean distance was adopted as the probability measure and the Ward's method as the clustering procedure. Statistical calculations were performed using Statistica version 7 and CANOCO for Windows 4.5 software.

\section{Results}

Based on the physico-chemical analysis of river waters, three types of habitat have been distinguished which were characterized by different water quality (Fig. 1). The Rospuda and Piecówka Rivers were the first group, which was characterized by increased organic matter content (Table 1). The second group included the Kamienny Bród River, which was characterized by high concentrations of TIN, chloride and sulphate(VI) ions as well as EC (Table 1). The last group was represented by Czarna Hańcza and Netta Rivers, which have low concentrations of carbon, nitrogen, phosphorous and sulphate(VI) and chloride ions (Table 1).

A total of 49 fungal species were identified based on PCR ITS-RFLP and DNA sequencing methods. However, RFLP-PCR method has proved to be sufficient to determine the species of 34 fungi. The highest taxonomic diversity was determined for the waters of the Piecówka and Rospuda Rivers, where 32 and 37 species were recorded, respectively. The dominant species in both rivers were Helicoon gigantisporum, Heliscus lugdunensis, and Tetracladium maxilliforme. Moreover, Achlya sp. preponderated in Piecówka River and Pythium sp. in Rospuda River. The lowest diversity was found in the Netta and Czarna Hańcza Rivers (20 and 15 species, respectively) (Table 2). The dominant species in both rivers were Leptomitus lacteus and Lemonniera aquatica. It was found that Clavariopsis aquatica was the most common species in Kamienny Bród River, where 22 species were identified. From the 49 identified species, 23 (47\%) matched with species belonging to the aquatic hyphomycetes group. Moreover, the studied rivers also showed occurrence of potentially pathogenic fungi, dominated by Candida albicans, Acremonium implicatum, Chrysosporium

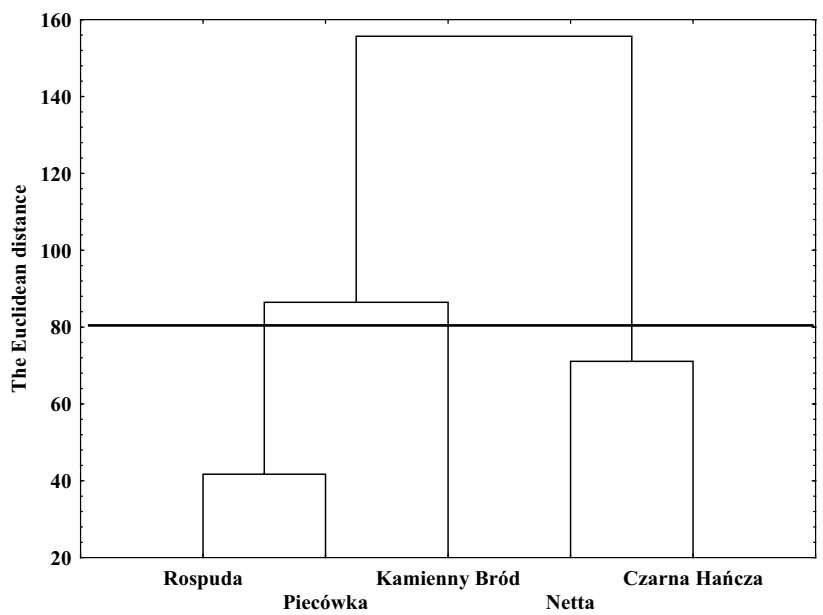

Fig. 1 Result of the cluster analysis of the the selected rivers of the Augustów Laceland in NE Poland 
Table 2 Taxonomic diversity of aquatic fungi in the selected rivers of the Augustów

Lakeland (accession numbers of the reference strains in GenBank are provided in brackets) italic rowspotentially pathogenic fungi

\begin{tabular}{|c|c|c|c|c|c|c|}
\hline \multirow[t]{2}{*}{ No } & \multirow[t]{2}{*}{ Species } & \multicolumn{5}{|l|}{ Rivers } \\
\hline & & $\begin{array}{l}\text { Kami- } \\
\text { enny } \\
\text { Bród }\end{array}$ & Piecówka & Rospuda & Netta & Czarna Hańcza \\
\hline 1 & $\begin{array}{l}\text { Achlya americana } \\
\text { (HQ643084.1) }\end{array}$ & $\times$ & $x$ & $x$ & & \\
\hline 2 & $\begin{array}{l}\text { Achlya flagellata } \\
\text { (HQ643097.1) }\end{array}$ & & $\times$ & $\times$ & & \\
\hline 3 & $\begin{array}{l}\text { Achlya oligacantha } \\
\text { (HQ643101.1) }\end{array}$ & & $\times$ & $x$ & $\times$ & \\
\hline 4 & $\begin{array}{l}\text { Acremonium implicatum } \\
(J Q 910163.1)\end{array}$ & $x$ & & $x$ & & \\
\hline 5 & $\begin{array}{l}\text { Alatospora acuminata } \\
\text { (KF730797.1) }\end{array}$ & & & $x$ & $x$ & \\
\hline 6 & $\begin{array}{l}\text { Alatospora flagellata } \\
\text { (KC834041.1) }\end{array}$ & & & $x$ & $\times$ & \\
\hline 7 & $\begin{array}{l}\text { Alternaria alternata } \\
\text { (AY354228.1) }\end{array}$ & $\times$ & $x$ & $x$ & & $x$ \\
\hline 8 & $\begin{array}{l}\text { Anguillospora crassa } \\
\text { (AY148106.1) }\end{array}$ & & $x$ & $\times$ & $\times$ & $x$ \\
\hline 9 & $\begin{array}{l}\text { Anguillospora filiformis } \\
\text { (JX089472.1) }\end{array}$ & & & $\times$ & $x$ & $x$ \\
\hline 10 & $\begin{array}{l}\text { Aphanomyces laevis } \\
\text { (HQ643122.1) }\end{array}$ & $\times$ & $x$ & $x$ & & \\
\hline 11 & $\begin{array}{l}\text { Apodachlya brachynema } \\
\text { (HQ643125.1) }\end{array}$ & $\times$ & $x$ & $x$ & & \\
\hline 12 & $\begin{array}{l}\text { Arthroderma insingulare } \\
\text { (AJ877213.1) }\end{array}$ & $x$ & & $x$ & $x$ & \\
\hline 13 & $\begin{array}{l}\text { Aspergillus fumigatus } \\
\text { (FJ867935.1) }\end{array}$ & & $\times$ & $\times$ & $\times$ & \\
\hline 14 & $\begin{array}{l}\text { Aspergillus niger } \\
\text { (JQ929761.1) }\end{array}$ & $\times$ & $x$ & $x$ & $x$ & $x$ \\
\hline 15 & $\begin{array}{l}\text { Candida albicans } \\
\text { (EF192231.1) }\end{array}$ & $x$ & $x$ & $x$ & & \\
\hline 16 & $\begin{array}{l}\text { Chrysosporium keratinophilum } G \\
\text { (KC923425.1) }\end{array}$ & $x$ & $x$ & & & \\
\hline 17 & $\begin{array}{l}\text { Clavariopsis aquatica } \\
\text { (GQ152143.1) }\end{array}$ & $x$ & & & $x$ & \\
\hline 18 & $\begin{array}{l}\text { Clavatospora longibrachiata } \\
\text { (KF730809.1) }\end{array}$ & $x$ & & & $x$ & $x$ \\
\hline 19 & $\begin{array}{l}\text { Exophiala dermatitidis } \\
\text { (KF996500.1) }\end{array}$ & $x$ & & & & \\
\hline 20 & $\begin{array}{l}\text { Flagellospora curvula } \\
\text { (KC834050.1) }\end{array}$ & & & $\times$ & & $x$ \\
\hline 21 & $\begin{array}{l}\text { Helicoon gigantisporum } \\
\text { (AY916467.1) }\end{array}$ & & $\times$ & $\times$ & & \\
\hline 22 & $\begin{array}{l}\text { Heliscus lugdunensis } \\
\text { (HQ897796.1) }\end{array}$ & & $\times$ & $\times$ & & \\
\hline 23 & $\begin{array}{l}\text { Lemonniera aquatica } \\
\text { (KF730823.1) }\end{array}$ & $\times$ & & & $x$ & $\times$ \\
\hline 24 & $\begin{array}{l}\text { Lemoniera centrosphaera } \\
\text { (KC834063.1) }\end{array}$ & & & $x$ & $x$ & \\
\hline 25 & $\begin{array}{l}\text { Leptomitus lacteus } \\
\text { (AF119597.1) }\end{array}$ & $\times$ & & & & \\
\hline 26 & $\begin{array}{l}\text { Lunulospora curvula } \\
\text { (JX089535.1) }\end{array}$ & & $x$ & $x$ & $x$ & \\
\hline
\end{tabular}


Table 2 (continued)

\begin{tabular}{|c|c|c|c|c|c|c|}
\hline \multirow[t]{2}{*}{ No } & \multirow[t]{2}{*}{ Species } & \multicolumn{5}{|l|}{ Rivers } \\
\hline & & $\begin{array}{l}\text { Kami- } \\
\text { enny } \\
\text { Bród }\end{array}$ & Piecówka & Rospuda & Netta & Czarna Hańcza \\
\hline 27 & $\begin{array}{l}\text { Microsporum gypseum } \\
\text { (EU151494.1) }\end{array}$ & $x$ & & $x$ & & \\
\hline 28 & $\begin{array}{l}\text { Penicillium funiculosum } \\
\text { (HQ637359.1) }\end{array}$ & $\times$ & $\times$ & $\times$ & $\times$ & \\
\hline 29 & $\begin{array}{l}\text { Pythium aquatile } \\
\text { (HQ643445.1) }\end{array}$ & & $x$ & $x$ & & \\
\hline 30 & $\begin{array}{l}\text { Pythium afertile } \\
\text { (HQ643416.1) }\end{array}$ & $\times$ & $x$ & & & \\
\hline 31 & $\begin{array}{l}\text { Pythium debaryanum } \\
\text { (HQ643519.1) }\end{array}$ & $\times$ & $\times$ & $\times$ & & \\
\hline 32 & $\begin{array}{l}\text { Pythium rostratum } \\
\text { (HQ643767.1) }\end{array}$ & & $\times$ & $\times$ & & \\
\hline 34 & $\begin{array}{l}\text { Pythium undulatum } \\
\text { (AY436638.1) }\end{array}$ & & & $\times$ & & \\
\hline 35 & $\begin{array}{l}\text { Rhodotorula rubra } \\
\text { (AB916512.1) }\end{array}$ & $\times$ & $\times$ & & & \\
\hline 36 & $\begin{array}{l}\text { Saprolegnia parasitica } \\
\text { (KC992717.1) }\end{array}$ & $\times$ & $\times$ & $\times$ & & \\
\hline 37 & $\begin{array}{l}\text { Tetracladium breve } \\
\text { (EU883431.1) }\end{array}$ & & $\times$ & $x$ & $\times$ & $x$ \\
\hline 38 & $\begin{array}{l}\text { Tetracladium furcatum } \\
\text { (GU586842.1) }\end{array}$ & & $x$ & $\times$ & $x$ & $x$ \\
\hline 39 & $\begin{array}{l}\text { Tetracladium marchalianum } \\
\text { (EU883423.1) }\end{array}$ & & $x$ & $x$ & $x$ & \\
\hline 40 & $\begin{array}{l}\text { Tetracladium maxilliforme } \\
\text { (KC989085.1) }\end{array}$ & & $\times$ & $x$ & & \\
\hline 41 & $\begin{array}{l}\text { Trichophyton violaceum } \\
\text { (JQ322678.1) }\end{array}$ & & $\times$ & & & \\
\hline 42 & $\begin{array}{l}\text { Trichosporon mucoides } \\
\text { (FJ515218.1) }\end{array}$ & $x$ & $\times$ & & & $x$ \\
\hline 43 & $\begin{array}{l}\text { Tricladium angulatum } \\
\text { (AY204610.1) }\end{array}$ & & $\times$ & $x$ & $x$ & $x$ \\
\hline 44 & $\begin{array}{l}\text { Tricladium patulum } \\
\text { (FJ000403.1) }\end{array}$ & & $\times$ & $\times$ & $\times$ & $x$ \\
\hline 45 & $\begin{array}{l}\text { Tricladium splendens } \\
\text { (DQ202511.1) }\end{array}$ & $\times$ & $\times$ & $x$ & $\times$ & \\
\hline 46 & $\begin{array}{l}\text { Tumularia aquatica } \\
\text { (FJ000399.1) }\end{array}$ & & & & $x$ & \\
\hline 47 & $\begin{array}{l}\text { Varicosporium delictum } \\
\text { (JQ412864.1) }\end{array}$ & & $x$ & $\times$ & $x$ & $x$ \\
\hline 48 & $\begin{array}{l}\text { Varicosporium elodeae } \\
\text { (JX981463.1) }\end{array}$ & & & $x$ & $\times$ & \\
\hline 49 & $\begin{array}{l}\text { Volucrispora graminea } \\
\text { (AJ748690.1) }\end{array}$ & & $\times$ & $x$ & $\times$ & $x$ \\
\hline
\end{tabular}

keratinophilum, Trichosporon cutaneum, and Rhodothorula rubra, particularly abundant in polluted rivers (Table 2). The presence of fungal species belonging to the aquatic hyphomycetes group was recorded in the waters of practically all of the studied rivers.

The total abundance of fungi in the waters of the studied rivers varied from $8200 \mathrm{CFU} / \mathrm{mL}$ in the Czarna Hańcza
River to 22,800 CFU/mL in the Piecówka River (Table 3). These were positively correlated with water EC $(r=0.88$, $P<0.01$ ), and negatively correlated with chlorophyll $a$ concentration ( $r=0.80, P<0.01)$, dissolved reactive phosphorus $(r=0.68, P<0.01)$ and TIN $(r=0.83, P<0.01)$. No statistically significant correlation was found between total fungal abundance and the concentration of DOC, POC, and phenol 
compounds (Fig. 2). The outcome of the RDA analysis is presented as a diplot containing environmental measurements and fungal species (Fig. 2). The first two principal components jointly accounted for $80.6 \%$ of the variance in the original variables for the waters of the analysed rivers, based on the hydrochemical parameters measured and the species composition of fungi from the aquatic hyphomycetes ecological group (Fig. 2). The RDA analysis revealed two main environmental clines (Fig. 2). Chlorophyll $a$, sulphate and chloride ions, TIN, DRP, SQ, CFU and EC formed the first cline, with chlorophyll $a$, sulphate and chloride ions, DRP, TIN vectors oriented opposite from EC, SQ and CFU. This indicates a negative correlation between these two groups of parameters. The second grouping was based on POC, DOC, phenols compounds, and pH with POC, phenols, DOC vectors oriented opposite to $\mathrm{pH}$ (Fig. 2).

\section{Discussion}

Research concerning the species diversity and abundance of fungi in rivers depending on their hydrochemical properties has only been sporadic so far [16, 21, 32, 33, 39]. Our research showed large species diversity of fungi in rivers water in which were identified potential pathogens and hyphomycetes, as well as zoosporic fungi belonging to genera Achlya sp., Aphanomyces sp., and Pythium sp.. They were predominant in the Piecówka and Rospuda Rivers. The dominance of species belonging to these fungal genera in flowing waters was also recorded by other authors [27, 45]. The abundance of fungi in the studied rivers was more than twice higher than in the lakes of the Augustów Lakeland [34], or the Augustów Canal [10]. It was caused by higher streamflow rate and water turbulence intensity result in the migration of fungi from sediments to the water depths [37]. Moreover, that is why more fungal species were identified in the river showing a higher streamflow rate (Netta River), but it is not the only factor determining the species diversity and abundance of fungi in rivers water. The research carried out on the rivers of south-west France showed that Alatospora acuminata and Clavariopsis aquatica were dominated [13] whereas in the rivers of north-east Poland analysed in the scope of the present study, their occurrence was less frequent. This may be related to the fact that both of the species prefer waters with acidic $\mathrm{pH}(4-5)[13,38]$ whereas the $\mathrm{pH}$ of the waters of the studied rivers of the Augustów Lakeland ranges from 7.52 to 7.81. The presence of Clavariopsis aquatica and Alatospora acuminata in waters with slightly alkaline $\mathrm{pH}$ suggests, however, that the occurrence of the species is particularly influenced by its streamflow rate. No presence of these species was also recorded in the slightly acidic waters of the dams of the Augustów Canal [10], or the lakes of the Augustów Lakeland [34], where water streamflow is hardly identifiable. Certain fungal species develop in a broad range of $\mathrm{pH}$ values, as confirmed by the study of Casas and Descals [9]. Potentially pathogenic fungal species predominated in waters with the highest $\mathrm{pH}$ values (Kamienny Bród River, Piecówka River, and Rospuda River). This is in accordance with the literature data, suggesting that alkalisation of the environment contributes to the development of potentially pathogenic fungi $[10,44]$.

Another important factor determining the species diversity of fungi is organic matter which constitute the basic sources of carbon for microfungi [15, 29]. However, Solé et al. [39] evidenced that species such as: Tetracladium marchalinum, Lemoniera centrosphaera, Alatospora flagellata, and Alatospora accuminata occur in waters irrespective of organic matter concentrations. Moreover, this list of fungi can be extended by such species as: Anguillospora crassa, Flagellospora curvula, Lunulospora curvula, Tetracladium breve, Tetracladium furcatum, Tricladium angulatum, Tricladium patulum, Tricladium splendens, Varicosporium delicatum, Varicosporium elodeae, and Volucrispora graminea according to our research. According to Solé et al. [39], species not tolerating high concentrations of organic carbon include: Anguillospora longissima, Clavariopsis aquatica, Lemoniera aquatica, and Clavatospora longibrachiata, what has been confirmed by our results. The highest total abundance and number of fungal species were recorded in rivers with high organic matter concentrations, which simultaneously recorded highest EC values and concentrations of sulphate(VI) and chloride ions, TIN, dissolved reactive phosphorus, constituting an indicator of water pollution of anthropogenic and agricultural origin. Sridhar et al. [40] and Pascoal et al. [32] stated that high abundance of hyphomycetes occur in waters polluted what also has been determined by our research. Krauss et al. [22, 23] found that the polluted waters of central Germany with high concentrations of sulphate(VI), nitrate(V), and orthophosphate(V) ions, recorded the presence of as many as 20 aquatic hyphomycetes species, dominated by Heliscus lugdunensis. This is not in accordance with the result of our own research, according to which the occurrence of Heliscus lugdunensis is independent of the concentration of sulphate(VI) and TIN in the waters of the studied rivers. It has been detected that this species is characteristic for the waters rich in nutrients provide conditions favourable for the development of a high number of microorganisms species. On the other hand, certain fungal species do not develop in waters with high concentrations of nitrate(V) ions [2, 24, 32, 41]. It has also been evidenced that water pollution usually leads to a decrease in the taxonomic diversity of aquatic hyphomycetes, including complete disappearance of species such as Tetracladium breve or Tricladium sp. [23, 32] what is in agreement with the results of the present research. Certain fungal species, such as Anguillospora crassa, Lunulospora 
Table 3 The average values (in bold) and minimum-maximum of selected parameters of rivers water quality

\begin{tabular}{|c|c|c|c|c|c|}
\hline \multirow[t]{2}{*}{ Parameters } & \multicolumn{5}{|l|}{ Rivers } \\
\hline & Kamienny Bród & Piecówka & Rospuda & Netta & Czarna Hańcza \\
\hline \multirow[t]{2}{*}{ Fungi abundance (CFU/mL) } & 21,975 & 22,250 & 19,000 & 11,450 & 9175 \\
\hline & $18,800-24,800$ & $19,800-24,200$ & $17,200-20,500$ & $10,000-12,200$ & $8200-10,200$ \\
\hline \multirow[t]{2}{*}{ Chlorophyll $a\left(\mu \mathrm{g} / \mathrm{dm}^{3}\right)$} & 7.48 & 1.71 & 5.33 & 3.14 & 13.8 \\
\hline & $3.96-10.5$ & $1.46-2.00$ & $4.91-6.00$ & $2.28-4.60$ & $11.9-17.0$ \\
\hline \multirow[t]{2}{*}{$\mathrm{EC}(\mu \mathrm{S} / \mathrm{cm})$} & 600 & 425 & 460 & 419 & 390 \\
\hline & $512-679$ & $393-460$ & $416-499$ & $382-500$ & $311-462$ \\
\hline \multirow[t]{2}{*}{$\mathrm{pH}$} & 7.74 & 7.58 & 7.57 & 7.81 & 7.85 \\
\hline & $7.55-8.05$ & $7.20-7.88$ & $7.13-8.17$ & $7.53-8.01$ & $7.29-8.16$ \\
\hline \multirow[t]{2}{*}{$\mathrm{POC}\left(\mathrm{mgC} / \mathrm{dm}^{3}\right)$} & 1.92 & 3.95 & 3.49 & 0.69 & 0.72 \\
\hline & $1.55-2.30$ & $3.52-4.30$ & $3.11-4.30$ & $0.56-0.78$ & $0.26-0.98$ \\
\hline \multirow[t]{2}{*}{$\mathrm{DOC}\left(\mathrm{mgC} / \mathrm{dm}^{3}\right)$} & 10.9 & 19.4 & 15.9 & 7.32 & 6.02 \\
\hline & $8.95-13.3$ & $16.8-23.2$ & $12.6-18.0$ & $4.96-9.27$ & $2.17-8.04$ \\
\hline \multirow[t]{2}{*}{ Phenols $\left(\mathrm{mgC} / \mathrm{dm}^{3}\right)$} & 0.96 & 1.11 & 0.75 & 0.58 & 0.48 \\
\hline & $0.85-1.06$ & $0.95-1.30$ & $0.55-0.89$ & $0.48-0.68$ & $0.37-0.59$ \\
\hline \multirow[t]{2}{*}{$\operatorname{TIN}\left(\mu \mathrm{gN} / \mathrm{dm}^{3}\right)$} & 1101 & 732 & 670 & 446 & 313 \\
\hline & $974-1233$ & $616-843$ & $586-770$ & $357-508$ & $234-433$ \\
\hline \multirow[t]{2}{*}{$\mathrm{DRP}\left(\mu \mathrm{gP} / \mathrm{dm}^{3}\right)$} & 133 & 123 & 118 & 96.3 & 93.9 \\
\hline & $106-137$ & $92.6-134$ & $116-121$ & $85.3-106$ & $90.4-95.7$ \\
\hline \multirow[t]{2}{*}{ Sulphate ions $\left(\mathrm{mg} / \mathrm{dm}^{3}\right)$} & 77.1 & 44.2 & 46.8 & 36.1 & 31.8 \\
\hline & $73.4-84.9$ & $33.7-51.6$ & $39.2-61.3$ & $29.7-41.3$ & $27.8-35.7$ \\
\hline \multirow[t]{2}{*}{ Chloride ions $\left(\mathrm{mg} / \mathrm{dm}^{3}\right)$} & 23.4 & 14.2 & 13.9 & 11.3 & 13.4 \\
\hline & $22.3-25.1$ & $12.8-15.3$ & $11.2-15.6$ & $10.5-13.0$ & $12.0-15.5$ \\
\hline
\end{tabular}

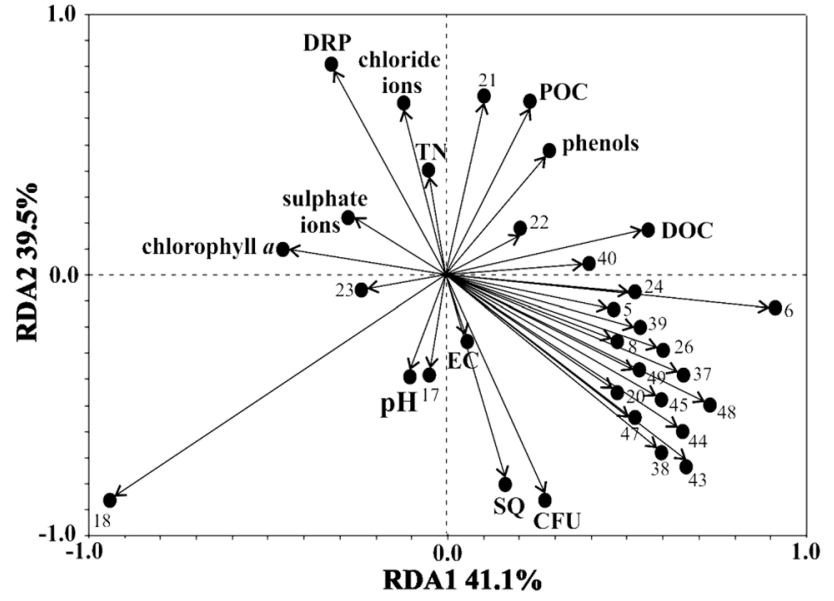

Fig. 2 RDA of abundance (CFU) and species diversity (numbers correspond to those of a given species in Table 2) of hyphomycetes, selected physico-chemical parameters of water quality and streamflow quantity (SQ) of analysed rivers water

curvula, Tetracladium breve, Tetracladium furcatum, Tricladium angulatum, Tricladium patulum, Tricladium splendens, Varicosporium delicatum, and Volucrispora graminea, were found to be negatively correlated with both TIN and sulphate(VI) and chloride ions. Therefore, they seem to be species preferring clean waters or waters with a moderate degree of pollution. Moreover, the polluted rivers were characterised by high number of potential pathogenic fungi, such as Candida albicans, Arthoderma insingulare, Exophiala dermatidis, Trichophyton violaceum, and Rhodothorula rubra. High nutrients concentrations in waters, and particularly dissolved reactive phosphorus, provide perfect conditions for the development of phytoplankton [10]. On the one hand, it has been evidenced that an increase in algal biomass results in a decrease in the biomass and species diversity of aquatic fungi, which may be related to a decrease in the level of biogenes, lower oxygen concentration in water, and high sensitivity of certain fungal species to cyanobacterial toxins [3,28]. On the other hand, fungi may inhibit algal growth, and particularly that of diatoms and cyanobacteria [36]. This is suggested by the results of the present research that revealed a negative correlation between the total abundance of fungi and chlorophyll $a$ concentration, constituting an indicator of algal biomass. A reversely proportional correlation was also recorded between chlorophyll $a$ concentration and certain hyphomycetes species. This also seems to be confirmed by the recorded negative correlation between these fungal species and TIN, necessary for the growth of algae and cyanobacteria. The presence of certain species in waters, however, is largely independent of 
the concentrations of chlorophyll $a$ or TIN. These include among others: Clavariopsis aquatica, Flagellospora curvula, Lemonniera aquatica, Clavatospora longibrachiata, and Heliscus lugdunensis. The species probably developed mechanisms permitting their functioning in the environment containing cyanobacterial toxins $[28,31,39]$.

The study results show that the minimum fungi abundance was in a river with low concentration of organic matter, but the highest fungal taxonomic biodiversity was in the waters abundant in organic matter and in rivers distinguished by higher streamflow quantity. Potentially pathogenic fungi mainly occur in the waters of polluted rivers. Moreover, factors affecting the structure of mycoplankton include water $\mathrm{pH}$, content of chlorophyll $a$ concentrations. The study results presented in this paper seem to provide another important reason for including data on the abundance and species diversity of mycoplankton in the assessment of the ecological and sanitary state of surface waters, in particular species of aquatic fungi that are potential pathogens.

Acknowledgements Microbiological study was done in Laboratory of Applied Microbiology, University of Bialystok, financed by grant "Specific Scientific Equipment" of the Ministry of Science and Higher Education in Poland. The Authors would like to thank the Department of Cytobiochemistry and the Laboratory of Molecular Biology for sharing the laboratory.

Open Access This article is distributed under the terms of the Creative Commons Attribution 4.0 International License (http://creativecommons.org/licenses/by/4.0/), which permits unrestricted use, distribution, and reproduction in any medium, provided you give appropriate credit to the original author(s) and the source, provide a link to the Creative Commons license, and indicate if changes were made.

\section{References}

1. APHA (2013) Standard methods for the examination of water and waste water, 18th edn. American Public Health Association Publications, Washington, DC

2. Artiges J, Romaní AM, Sabater S (2008) Effect of nutrients on sporulation and diversity of aquatic hyphomycetes on submerged substrata in a Mediterranean stream. Aquatic Bot 88:32-38

3. Bärlocher F (1992) The ecology of aquatic hyphomycetes. Ecological studies, vol. 94, Berlin, Springer

4. Biedunkiewicz A, Silicki A, Mazurkiewicz-Zapałowicz K (2007) Yeast-like fungi in selected bath of Szczecin. Limnol Rev 3:3-10

5. Biedunkiewicz A (2011) Selected microfungi postulated as bioindicators in the assessment of waters purity in Poland. In: Kodola $\mathrm{V}$ (ed) Innovation processes in ICSTI community. Production of clean water: challenges and innovative solutions, 4th edn. ICSTI, Poland pp 115-124

6. Biedunkiewicz A, Dynowska M, Ejdys E, Sucharzewska E (2013) Species diversity of yeast-like fungi in some eutrophic lakes in Olsztyn. Acta Mycol 48(1):61-71

7. Bowman RA (1998) A reevaluation of the chromic acid colorimetric procedure for soil organic carbon. Commun Soil Sci Plant Anal 29(3-4):501-508
8. Buesing N, Gessner MO (2006) Benthic bacterial and fungal productivity and carbon turnover in a freshwater marsh. Appl Environ Microbiol 72:596-605.

9. Casas JJ, Descals E (1997) Aquatic hyphomycetes from Mediterranean streams contrasting in chemistry and riparian canopy. Limnetica 13(2):45-55

10. Cudowski A, Pietryczuk A, Hauschild T (2015) Aquatic fungi in relation to the physical and chemical parameters of water quality in the Augustów Canal. Fungal Ecol 13:193-204

11. Damare S, Raghukumar C (2008) Fungi and macroaggregation in deep-sea sediments. Microb Ecol 56:168-177

12. Descals E (2007) Techniques for handling ingoldian fungi. In: Graça MAS, Bärlocher F, Gessner MO (eds) Methods to study litter decomposition. A practical guide. Springer, Dordrecht, pp 129-141

13. Fabre E (1998) Aquatic hyphomycetes in three rivers of southwestern France. III. Relationship between spatial and temporal dynamics. Can J Bot 76:115-121

14. Gaitanis G, Velegraki A, Frangoulis E, Mitroussia A, Tsigonia A, Tzimogianni A, Katsambas A, Legakis NJ (2002) Identification of Malassezia species from patient skin scales by PCRRFLP. Clin Microbiol Infect 8:162-173.

15. García-Pĕna I, Hernández S, Auria R, Revah S (2005) Correlation of biological activity and reactor performance in biofiltration of toluene with the fungus Paecilomyces variotii CBS115145. Appl Environ Microb 71:4280-4285

16. Górniak A, Więcko A, Cudowski A (2013) Fungi biomass in lowland rivers of North Eastern Poland: effects of habitat conditions and nutrient concentrations. Pol J Ecol 61(4):737-745

17. Gupta AK, Kohli Y, Summerbell RC (2000) Molecular differentiation of seven Malassezia species. J Clin Microbiol 38(5):1869-1875.

18. Hageskal G, Lima N, Skaar I (2009) The study of fungi in drinking water. Mycol Res 113:165-172

19. Hall TA (1999) BioEdit: a user-friendly biological sequence alignment editor and analysis program for Windows 95/98/NT. Nucleic Acids Symp Ser 41:95-98

20. Jobard M, Rasconi S, Sime-Ngando T (2010) Diversity and functions of microscopic fungi: a missing component in pelagic food webs. Aquat Sci 72:255-268

21. Jorgensen NOG, Stepanauskas R (2009) Biomass of pelagic fungi in Baltic rivers. Hydrobiologia 623:105-112

22. Krauss G, Bärlocher F, Schreck P, Wennrich R, Glässer W, Krauss GJ (2001) Aquatic hyphomycetes occur in polluted waters in Central Germany. Nova Hedwig 72:419-428

23. Krauss G, Bärlocher F, Krauss GJ (2003) Effect of pollution on aquatic hyphomycetes. In: Tsui CKM, Hyde KD (eds) Freshwater mycology, research series, vol 10. Fungal Diversity Press, Hong Kong, pp 211-230

24. Krauss G, Schlosser D, Krauss GJ (2005) Aquatic fungi in heavy metal and organically polluted habitats. In: Deshmukh SK, Rai MK (eds) Biodiversity of fungi: their role in human life. Science Publishers, Inc., Enfield, pp 221-246

25. Lešp J, Šmilauer P (2003) Multivariate analysis of ecological data using CANOCO. Cambridge University Press, Cambridge

26. Lowry OH, Rosebrough NJ, Farr AL, Randall RJ (1951) Protein measurement with the Folin phenol reagent. J Biol Chem 193:265-275

27. Marano AV, Steciow MM (2006) Frequency and abundance of zoosporic fungi in some lotic environments of Buenos Aires Province (Argentina). J Agric Technol 2(1):17-28

28. Medeiros AO, Pascoal C, Graca MAS (2009) Diversity and activity of aquatic fungi under low oxygen conditions. Freshw Biol 54:142-149 
29. Middelhoven WJ, Spaaij F (1997) Rhodotorula cresolica sp. nov., a cresol assimilating yeast species isolated from soil. Int J Syst Bacteriol 47:324-327

30. Nikolcheva LG, Bärlocher F (2005) Seasonal and substrate preferences of fungi colonizing leaves in streams: traditional versus molecular evidence. Environ Microbiol 7:270-280

31. Pascoal C, Cássio F (2004) Contribution of fungi and bacteria to leaf litter decomposition in a polluted river. Appl Environ Microb 70:5266-5273

32. Pascoal C, Marvanová L, Cássio F (2005) Aquatic hyphomycetes diversity in streams of Northwest Portugal. Fungal Divers 19:109-128

33. Pietryczuk A, Górniak AS, Więcko A, Cudowski A (2013) Fungi of the Vistula River and its main tributaries- biomass, abundance and sensitivity to antibiotics and antimycotics. Acta Mycol 48(2):235-243

34. Pietryczuk A, Cudowski A, Hauschild T (2014) Effect of trophic status in lakes on fungal species diversity and abundance. Ecotoxicol Environ Saf 109:32-37

35. PN-86, C-05560/02, Polish Standard (1986) Water and waste water, tests for chlorophyll in surface water, determination of chlorophyll $a$ in planktonic algae by spectrophotometric monochromatic method with correction for pheopigments $a$, Polish Committee for Standardisation

36. Rasconi S, Jobard M, Sime-Ngando T (2011) Parasitic fungi of phytoplankton: ecological roles and implications for microbial food webs. Aquat Microb Ecol 62:123-137

37. Ravikumar S, Thirumalairaj J, Gokulakrishnan R (2013) Assessment of microbial diversity in relation to biochemical constituents along Palk Strait. Int J Innov Res Sci Eng Technol 2(11):6431-6437

38. Rosset J, Bärlocher F (1985) Aquatic hyphomycetes: influence of ph, $\mathrm{Ca}^{2+}$ and $\mathrm{HCO}_{3}{ }^{-}$on growth in vitro. Trans $\mathrm{Br}$ Mycol Soc 84(1):137-145

39. Solé M, Fetzer I, Wennrich R, Sridhar KR, Harms H, Krauss G (2008) Aquatic hyphomycetes communities as potential bioindicators for assessing anthropogenic stress. Sci Total Environ 389:557-565

40. Sridhar KR, Krauss G, Bärlocher F, Wennrich R, Krauss GJ (2000) Fungal diversity in heavy metal polluted waters in central Germany. Fungal Divers 5:119-129

41. Sridhar KR, Krauss G, Bärlocher F, Raviraja NS, Wennrich R, Baumbach R, Krauss GJ (2001) Decomposition of alder leaves in two heavy metal-polluted streams in Central Germany. Aquat Microb Ecol 26:73-80

42. ter Braak CJF (1994) Canonical community ordination. Part I: basic theory and linear methods. Ecoscience 1:127-140

43. Van Wijngaarden RPA, van den Brink PJ, Voshaar JHO, Leeuwangh P (1995) Ordination techniques for analyzing response of biological communities to toxic stress in experimental ecosystems. Ecotoxicology 4:61-77

44. Vylkova S, Carman AJ, Danhof HA, Collette JR, Zhou H, Lorenz MC (2011) The fungal pathogen Candida albicans autoinduces hyphal morphogenesis by raising extracellular $\mathrm{pH}$. $\mathrm{mBio}$ 2(3): e00055-e00011

45. Yanna Ho WH, Hyde KD, Goh TK (2001) Occurrence of fungi on tissues of Livistona chinensis. Fungal Divers 6:167-180 